\title{
KOSAKATA SEHARI-HARI KELOMPOK TRANSEKSUAL DI KECAMATAN PAKIS KABUPATEN MALANG
}

\author{
Teguh Prasetya \\ Sekolah Menengah Kejuruan Multimedia Malang \\ teguh_pras@yahoo.co.id
}

\begin{abstract}
Abstrak: Penelitian ini mendeskripsikan kosakata sehari-hari kelompok transeksual yang mempunyai karakter unik di Kecamatan Pakis Kabupaten Malang. Penelitian ini menggunakan pendekatan kualitatif. Metode yang digunakan adalah analisis deskriptif. Sumber data penelitian ini berupa informan kelompok sosial transeksual di Kecamatan Pakis Kabupaten Malang. Data dalam penelitian ini berupa rekaman komunikasi yang dilakukan terhadap informan (transeksual) di salon tempat mereka berkerja. Teknik pengumpulan data dalam penelitian ini adalah observasi, perekaman, catatan lapangan, dan wawancara. Analisis data menggunakan model Miles dan Huberman. Hasil penelitian menggambarkan wujud kosakata sehari-hari kelompok transeksual berupa tanda, kode, simbol, dan permainan bunyi yang hanya dapat dipahami antaranggota kelompok. Kosakata ini menjadi kode rahasia dan bahasa pergaulan yang mencerminkan kekhususan penuturnya.
\end{abstract}

Kata kunci: kosakata, kelompok transeksual

\begin{abstract}
This study described transsexual groups' unique everyday vocabulary. This study used a qualitative approach with the descriptive analysis method. The data source a transsexual informant group in Pakis, Malang Regency. The data were a record of communication made by the transsexual informant in barber shop where they work. The data were collected observation, recording, field notes, and interviews. The data were analyzed by using Miles and Huberman's model. The results of the study depicted the transsexual groups' everyday vocabulary in the form of signs, codes, symbols, and sound manipulation that could only be understood among members of the group. This vocabulary became a secret code and jargon that reflects the uniqueness of speakers.
\end{abstract}

Keywords: vocabulary, transsexual group

\section{PENDAHULUAN}

Bahasa sangat berperan dalam kehidupan manusia. Semua aktivitas manusia tidak terlepas dari adanya pemakaian bahasa. Kehidupan manusia normal tidak dapat dipisahkan dari bahasa. Bahasa masuk ke pemikiran-pemikiran manusia, menjembatani hubungan manusia yang satu dengan manusia yang lain, dan bukan menyelinap masuk ke dalam aliran mimpi. Perangkat pengetahuan manusia yang bersifat sosial banyak juga tersimpan dan disebarluaskan melalui bahasa (Ohoiuwutun dalam Nopianti, 2007: 2).

Bahasa sebagai alat komunikasi sosial setidaknya mengisyaratkan bahwa bahasa mempunyai alat komunikasi yang penting untuk membangun konsep diri sebagai manusia, aktualisasi diri, untuk kelangsungan hidup, untuk memperoleh kebahagiaan, terhindar dari tekanan dan tegangan (Wurianto, 2015: 126). Antara lain lewat komunikasi yang bersifat menghibur dan memupuk hubungan dengan orang lain. Melalui komunikasi secara tidak langsung kita bekerja sama dengan anggota masyarakat (keluarga, kelompok belajar, perguruan tinggi, RT, RW, desa, kota, dan negara secara keseluruhan) untuk mencapai tujuan bersama.

Berlatar belakang dengan bahasa sebagai alat komunikasi, Mujianto (2003: 156) menjelaskan dua macam variasi bahasa jika dibedakan dari aspek penutur bahasa, yaitu: (1) Variasi bahasa bersifat perorangan yang lazim disebut idiolek, dan (2) Variasi bahasa bersifat kelompok. Variasi bersifat kelompok sosial antara lain meliputi: (1) variasi bahasa berdasarkan pada wilayah atau area tempat tinggal, lazim disebut dialek areal atau dialek regional, dialek geografi, dan atau dialek saja; (2) variasi bahasa didasarkan pada waktu atau masa tertentu, lazim disebut dialek temporal atau kronolek; (3) variasi bahasa berdasarkan pada status sosial, golongan atau kelas sosial, lazim disebut dialek sosial atau sosiolek. Berdasarkan pada status golongan dan 
kelas sosial ini variasi bahasa terbagi atas akrolek, basilek, vulgar, slang, kolokial, jargón, dan prokem.

Bahasa ditinjau dari segi sosiolinguistik senantiasa memperhitungkan bagaimana pemakainya di dalam masyarakat yang dipengaruhi oleh faktorfaktor sosial tertentu. Faktor-faktor sosial itu antara lain: status sosial, tingkat pendidikan, umur, tingkat ekonomi, agama, jenis kelamin, dan lain-lain. Selain itu, bentuk bahasanya juga dipengaruhi oleh faktor situasional, misalnya, siapa yang berbicara, bagaimana bentuk bahasanya, kepada siapa, di mana, kapan, dan mengenai masalah apa. Rentetan peristiwa tersebut biasanya disebut dengan sosiolek (Mujianto, 2003: 19).

Sosiolek merupakan bagian dari variasi bahasa dari segi penutur selain idiolek, dialek, dan kronolek. Sosiolek biasa disebut juga dengan dialek sosial, yaitu variasi bahasa yang berkenaan dengan status dan kelas sosial para penuturnya. Dalam Sosiolinguistik, biasanya variasi inilah (sosiolek) yang paling banyak dibicarakan dan paling banyak menyita waktu untuk membicarakannya, karena variasi ini menyangkut semua masalah pribadi para penuturnya, seperti usia, pendidikan, seks, pekerjaan, tingkat kebangsawanan, dan keadaan sosial ekonomi (Chaer \& Leoni Agustina, 1995: 29).

Pateda (1990: 36) mengemukakan berdasarkan usia, dapat dilihat perbedaan di antara variasi bahasa yang digunakan oleh anak-anak, para remaja, orang dewasa, dan orang yang tergolong lansia. Jika diperhatikan bahasa yang mereka gunakan, pasti dapat dilihat perbedaannya, bukan berkenaan dengan isinya (isi pembicaraan), melainkan perbedaan dalam bidang morfologi, sintaksis, dan juga kosakata.

Berdasarkan pendidikan, para penutur yang beruntung memperoleh pendidikan tinggi, akan berbeda variasi bahasanya dengan mereka yang hanya berpendidikan menengah, rendah, bahkan yang tidak berpendidikan sama sekali. Perbedaan yang paling jelas adalah dalam bidang kosakata, pelafalan, morfologi, dan sintaksis.

Berdasarkan pembagian seks (jenis kelamin) penutur dapat dilihat adanya dua jenis variasi bahasa, yaitu jika diperhatikan antara percakapan sekelompok mahasiswi atau ibu-ibu. Lalu dibandingkan dengan percakapan yang dilakukan antara sekelompok mahasiswi atau bapak-bapak. Maka, dapat dilihat perbedaan variasi antara keduanya.

Berdasarkan perbedaan pekerjaan, profesi jabatan, atau tugas para penutur dapat juga menyebabkan adanya variasi sosial. Jika diperhatikan "bahasa" para buruh atau tukang, pedagang kecil, pengemudi kendaraan umum, para guru, para mubalig, dan para pengusaha, maka kita dapat melihat pula perbedaan variasi bahasanya (Sundari, 2007: 87). Perbedaan bahasa mereka terutama karena lingkungan tugas mereka dan apa yang mereka kerjakan. Perbedaan variasi bahasa mereka terutama tampak pada bidang kosakata yang mereka gunakan.

Berdasarkan tingkat-tingkat kebangsawanan dapat pula variasi bahasa yang berkenaan dengan tingkat-tingkat kebangsawanan itu. Bahasa Jawa, bahasa Bali, bahasa Sunda mengenal variasi kebangsawanan ini, tetapi bahasa Indonesia tidak (Sundari, 2007: 98). Berdasarkan keadaan sosial ekonomi para penutur, dapat juga menyebabkan adanya variasi bahasa, pembedaan kelompok masyarakat berdasarkan status sosial ekonomi ini tidak sama dengan pembedaan berdasarkan tingkat kebangsawanan, sebab dalam zaman modern ini memperoleh status sosial yang tinggi tidak lagi identik status kebangsawanan yang tinggi tetapi tidak memiliki status sosial ekonomi yang tinggi, begitu pula sebaliknya.

Pemakaian bahasa di antara masing-masing lingkungan sosial, biasa ditandai dengan bentuk dialek sosial. Setiap kelompok sosial ada yang bersifat tertutup. Kekhasan bahasa dalam kelompok sosial yang ada bersifat tertutup (Pateda, 1987: 54). Artinya, ada kode-kode linguistik yang hanya bisa dimengerti oleh anggota kelompok sosial yang sama, misalnya kelompok sosial transeksual di Kecamatan Pakis Kabupaten Malang yang dalam keseharianya menggunakan bahasa slang untuk berkomunikasi, yang pada dasarnya bahasa yang mereka gunakan bersifat tertutup dan rahasia dan hanya dapat dimengerti oleh anggota kelompoknya.

Anggota kelompok sosial ini memiliki istilah khusus yang dipakai dalam konteks anggota kelompok transeksual. Dipakainya istilah-istilah tersendiri umumnya menghindari kemungkinan pemahaman dari orang lain di luar anggota kelompok. Tertutupnya bahasa yang dimiliki kelompok ini terkait erat dengan pandangan masyarakat terhadap profesi transeksual salon yang sering dipandang hina oleh masyarakat, sehingga para transeksual yang bekerja di salon berusaha menutupi identitas diri dan perilakunya dengan bahasa. Terbukti kosakata khusus itu dominan untuk dapat dilakukanya aktivitas komunikasi kelompok transeksual. Jadi, ketertutupan bahasa kelompok transeksual pada dasarnya merupakan refleksi perilaku kehidupan di masyarakat yang layak dikaji. 


\section{METODE}

Penelitian ini merupakan penelitian bahasa dalam ranah sosiolinguistik dengan menggunakan pendekatan kualitatif. Metode yang digunakan dalam penelitian ini adalah analisis deskriptif. Data dalam penelitian ini berupa rekaman komunikasi yang dilakukan oleh informan di tempat mereka berkerja yaitu salon. Sumber data penelitian ini berupa informan yang kesemuanya adalah kelompok sosial transeksual di Kecamatan Pakis Kabupaten Malang. Teknik pengumpulan data dalam penelitian ini adalah observasi, perekaman, catatan lapangan, dan wawancara. Setelah data terkumpul dilakukan proses klasifikasi selanjutnya dilakukan analisis. Analisis data menggunakan model Miles dan Huberman (Moleong, 2005: 45).

\section{HASIL DAN PEMBAHASAN}

Kosakata sehari-hari yang digunakan oleh kelompok sosial transeksual di Kecamatan Pakis Kabupaten Malang dapat diidentifikasi adanya kurang lebih Seratus kosakata sehari-hari yang sering digunakan kelompok sosial transeksual saat berkomunikasi.

Adapun bahasa slang yang digunakan kelompok sosial transeksual yang berwujud kosakata seharihari, terlihat dalam data pada tabel berikut.

Tabel 1 Tabel Kosakata Sehari-hari

\begin{tabular}{|l|l|l|}
\hline No & \multicolumn{1}{|c|}{ Kosakata } & \multicolumn{1}{c|}{ Kata Standart } \\
\hline 1 & Adinda & Ada \\
\hline 2 & $\begin{array}{l}\text { Ampar-ampar } \\
\text { pisang }\end{array}$ & Tidak apa-apa \\
\hline 3 & Ani- ani & Anak-anak \\
\hline 4 & Arebong & Arab \\
\hline 5 & Bagaskara & Bagus \\
\hline 6 & Banyenyong & Banyak \\
\hline 7 & Barunawati & Baru \\
\hline 8 & Bawang & Bau \\
\hline 9 & Bejongan & Baju \\
\hline 10 & Belalang & Beli \\
\hline 11 & Belanda & Belum \\
\hline 12 & Bepong & Bapak \\
\hline 13 & Bias-bias kasih & Biasa \\
\hline 14 & Binojin & Pacar/Kekasih \\
\hline 15 & Bisikan & Bisa \\
\hline 16 & Blejongan & Belanja \\
\hline 17 & Bodrexin & Bodoh \\
\hline 18 & Bolenawati & Boleh \\
\hline 19 & Brepongan & Berapa \\
\hline 20 & Cakra & Ganteng \\
\hline 21 & Capcus & Cepat \\
\hline 22 & Capung & Capek \\
\hline & & \\
\hline
\end{tabular}

\begin{tabular}{|c|c|c|}
\hline 23 & Celenong & Celana \\
\hline 24 & Desek & Dia \\
\hline 25 & Duding & Duduk \\
\hline 26 & Duta & Uang \\
\hline 27 & Ekek & Saya \\
\hline 28 & Enem pelong & $\begin{array}{l}\text { Enam Puluh ribu } \\
\text { rupiah }\end{array}$ \\
\hline 29 & Etes-etes & Hati-Hati \\
\hline 30 & Eyes & Cantik \\
\hline 31 & Gegong & Gigi \\
\hline 32 & Gejongan & Gaji \\
\hline 33 & Gembala & Gemuk \\
\hline 34 & Grimsi & Gerimis \\
\hline 35 & Habibah & Habis \\
\hline 36 & Harem & Jelek \\
\hline 37 & Helmi yahya & Helm \\
\hline 38 & Hempina & Handphone \\
\hline 39 & Hitachi & Hitam \\
\hline 40 & Husni & Hujan \\
\hline 41 & Ikatan & Ikut \\
\hline 42 & Ines & Ini \\
\hline 43 & Isabella & Sebelah \\
\hline 44 & Isnaini & Malu \\
\hline 45 & Jakarta & Jaket \\
\hline 46 & Jali-jali & Jalan-Jalan \\
\hline 47 & Jauhari & Jauh \\
\hline 48 & Jelita & Jelek \\
\hline 49 & Jembong & $\begin{array}{l}\text { Menarik/Menjamba } \\
\mathrm{k}\end{array}$ \\
\hline 50 & Jula-juli & Jual Beli \\
\hline 51 & Kampingan & Kapan \\
\hline 52 & Katarina & Kotor \\
\hline 53 & Kayangan & Kaya \\
\hline 54 & Kekong & Kaki \\
\hline 55 & Keles & Sungai \\
\hline 56 & Kemandra & Kemana \\
\hline 57 & Kentucky & Kentut \\
\hline 58 & Kerintangan & Keriting \\
\hline 59 & Kerajaan & Kerja \\
\hline 60 & Keredongan & Berjilbab \\
\hline 61 & Kulsek & Kuliah \\
\hline 62 & Kuncira & Kunci \\
\hline 63 & Kurnia & Kurang \\
\hline 64 & Lacita & Lancang \\
\hline 65 & Lambreta & Lambat \\
\hline 66 & Lamongan & Lama \\
\hline 67 & Lampringan & Sedang apa \\
\hline 68 & Lapangan bola & Lapar \\
\hline 69 & Lebrong & Libur \\
\hline 70 & Lehes & Lihat \\
\hline 71 & Limang pelong & $\begin{array}{l}\text { Lima Puluh ribu } \\
\text { rupiah }\end{array}$ \\
\hline 72 & Lupita & Lupa \\
\hline 73 & Makasar & Makan \\
\hline 74 & Mak lampir & Malam \\
\hline 75 & Malasyia & Malas \\
\hline 76 & Manda & Mana \\
\hline 77 & Mandala & Mandi \\
\hline 78 & Maskap & Masuk \\
\hline
\end{tabular}


Lanjutan Tabel 1 Tabel Kosakata Sehari-hari

\begin{tabular}{|l|l|l|}
\hline 79 & Mehong & Mahal \\
\hline 80 & Merana & Merah \\
\hline 81 & Merong & Marah \\
\hline 82 & Metes & Mati \\
\hline 83 & Minentiner & $\begin{array}{l}\text { Terlalu Percaya } \\
\text { Diri }\end{array}$ \\
\hline 84 & Minima & Minum \\
\hline 85 & Miskana & Miskin \\
\hline 86 & Mukria & Muka \\
\hline 87 & Ngantra & Mengantuk \\
\hline 88 & Ngobras-ngobras & Ngomong-ngomong \\
\hline 89 & Ngumsek & Mencuci \\
\hline 90 & Organda & Orang \\
\hline 91 & Pagina & Pagi \\
\hline 92 & Pastelan & Pasti \\
\hline 93 & Pendekar & Pendek \\
\hline 94 & Peres & Bohong \\
\hline 95 & Petang pelong & $\begin{array}{l}\text { Empat Puluh ribu } \\
\text { rupiah }\end{array}$ \\
\hline 96 & Pleni-pleni & Pelan-Pelan \\
\hline 97 & Polonia & Pulang \\
\hline 98 & Prutinus & Perut \\
\hline 99 & Pulsinus & Pulsa \\
\hline 100 & Putira & Putih \\
\hline & & \\
\hline
\end{tabular}

Berdasarkan Tabel 1, dapat dipahami bahwa ada seratus kosakata yang sering digunakan oleh kelompok sosial transeksual untuk berkomunikasi sehari-hari. Orang lain di luar anggota kelompok sosial transeksual pada umumnya sedikit mengerti tentang kosakata yang digunakan sehari-hari ini oleh kelompok sosial transeksual, namun hanya beberapa kosakata saja yang dimengerti. Hal ini disebabkan karena dari pihak kelompok sosial transeksual lebih sering mengucapkan sebagian kosakata yang sudah lazim digunakan di dalam salon dalam keseharianya. Adapun contoh kosakata itu adalah Adinda, Perez, Rumpik, Puyunghai dan yenya.

Selanjutnya kata-kata tersebut digunakan sebagai tuturan kepada orang lain sebagaimana tabel di bawah ini.

Tabel 2 Tabel Keterangan Kosakata Sehari-hari

\begin{tabular}{|l|l|}
\hline \multicolumn{1}{|c|}{ Kosakata } & Keterangan \\
\hline Adinda & $\begin{array}{l}\text { Kata 'adinda' mempunyai } \\
\text { arti kata yaitu 'ada'. Istilah } \\
\text { ini biasanya digunakan oleh } \\
\text { kelompok sosial transeksual } \\
\text { untuk memberi informasi } \\
\text { kepada customer tentang } \\
\text { produk kecantikan yang } \\
\text { tersedia di salon. }\end{array}$ \\
\hline
\end{tabular}

\begin{tabular}{|c|c|}
\hline $\begin{array}{l}\text { Ampar-ampar } \\
\text { pisang }\end{array}$ & $\begin{array}{l}\text { Kata 'ampar-ampar pisang' } \\
\text { mempunyai arti kata yaitu } \\
\text { 'tidak apa-apa'. Istilah ini } \\
\text { biasanya digunakan oleh } \\
\text { kelompok sosial transeksual } \\
\text { untuk menunjukkan rasa } \\
\text { jengkelnya kepada customer } \\
\text { yang membayar dengan uang } \\
\text { yang kurang. }\end{array}$ \\
\hline Ani-ani & $\begin{array}{l}\text { Kata 'ani-ani' mempunyai } \\
\text { arti kata yaitu 'anak-anak'. } \\
\text { Istilah ini biasanya digunakan } \\
\text { oleh kelompok sosial } \\
\text { transeksual untuk menyebut } \\
\text { customer di bawah umur } \\
\text { (anak-anak) yang datang dan } \\
\text { hendak mencukur rambutnya } \\
\text { di salon. }\end{array}$ \\
\hline Arebong & $\begin{array}{l}\text { Kata 'arebong' mempunyai } \\
\text { arti kata yaitu 'arab'. Istilah } \\
\text { ini biasanya digunakan oleh } \\
\text { kelompok sosial transeksual } \\
\text { untuk menyebut seseorang } \\
\text { yang beretnis 'Arab'. }\end{array}$ \\
\hline Bagaskara & $\begin{array}{l}\text { Kata 'bagaskara' mempunyai } \\
\text { arti kata yaitu 'bagus'. Istilah } \\
\text { ini biasanya digunakan oleh } \\
\text { kelompok sosial transeksual } \\
\text { untuk memuji sesuatu yang di } \\
\text { anggap bagus. }\end{array}$ \\
\hline Banyenyong & $\begin{array}{l}\text { Kata 'banyenyong' } \\
\text { mempunyai arti kata yaitu } \\
\text { 'banyak'. Istilah ini biasanya } \\
\text { digunakan oleh kelompok } \\
\text { sosial transeksual untuk } \\
\text { mengungkapkan rasa } \\
\text { jengkelnya kepada salesman } \\
\text { yang menawarkan barang } \\
\text { kebutuhan salon. }\end{array}$ \\
\hline Barunawati & $\begin{array}{l}\text { Kata 'barunawati' } \\
\text { mempunyai arti kata } \\
\text { yaitu 'baru'. Istilah ini } \\
\text { biasanya digunakan oleh } \\
\text { kelompok sosial transeksual } \\
\text { untuk memberikan informasi } \\
\text { kepada customer tentang } \\
\text { produk-produk kecantikan } \\
\text { yang baru di salon. }\end{array}$ \\
\hline Bawang & $\begin{array}{l}\text { Kata 'bawang' mempunyai } \\
\text { arti kata yaitu 'bau'. Istilah } \\
\text { ini biasanya digunakan oleh } \\
\text { kelompok sosial transeksual } \\
\text { untuk menyatakan } \\
\text { kejengkelanya apabila } \\
\text { terdapat bau yang tidak sedap } \\
\text { di dalam salon. }\end{array}$ \\
\hline
\end{tabular}


Lanjutan Tabel 2 Tabel Keterangan Kosakata Seharihari

\begin{tabular}{|c|c|}
\hline Bejongan & $\begin{array}{l}\text { Kata 'bejongan' mempunyai } \\
\text { arti kata yaitu 'baju'. Istilah } \\
\text { ini biasanya digunakan oleh } \\
\text { kelompok sosial transeksual } \\
\text { saat memuji baju yang } \\
\text { dikenakan oleh temannya } \\
\text { yang sesama transeksual. }\end{array}$ \\
\hline Belalang & $\begin{array}{l}\text { Kata 'belalang' mempunyai } \\
\text { arti kata yaitu 'beli'. Istilah } \\
\text { ini biasanya digunakan oleh } \\
\text { kelompok sosial transeksual } \\
\text { saat membeli barang-barang } \\
\text { kebutuhan salon. }\end{array}$ \\
\hline Belanda & $\begin{array}{l}\text { Kata 'belanda' mempunyai } \\
\text { ati kata yaitu 'belum'. Istilah } \\
\text { ini biasanya digunakan oleh } \\
\text { kelompok sosial transeksual } \\
\text { ketika menjawab pertayaan } \\
\text { transeksual lainya yang } \\
\text { menawarkan makan atau } \\
\text { menayakan pekerjaan yang } \\
\text { tidak cepat selesai. }\end{array}$ \\
\hline Bepong & $\begin{array}{l}\text { Kata 'bepong' mempunyai } \\
\text { arti kata yaitu 'Bapak' atau } \\
\text { Ayah'. Istilah ini biasanya } \\
\text { digunakan oleh kelompok } \\
\text { sosial transeksual untuk } \\
\text { menyebut nama 'Bapak atau } \\
\text { Ayah'. }\end{array}$ \\
\hline Bias-bias kasih & $\begin{array}{l}\text { Kata 'bias-bias kasih' } \\
\text { mempunyai arti kata yaitu } \\
\text { 'biasa-biasa saja'. Istilah ini } \\
\text { biasanya digunakan oleh } \\
\text { kelompok sosial transeksual } \\
\text { ketika memaki orang yang } \\
\text { berpenampilan biasa-biasa } \\
\text { saja. }\end{array}$ \\
\hline Binojin & $\begin{array}{l}\text { Kata 'binojin' mempunyai } \\
\text { arti kata yaitu 'pacar atau } \\
\text { kekasih'. Istilah ini biasanya } \\
\text { digunakan oleh kelompok } \\
\text { sosial transeksual untuk } \\
\text { memberi informasi kepada } \\
\text { orang lain nama sang pujaan } \\
\text { hati, dalam hal ini 'pacar atau } \\
\text { kekasih'. }\end{array}$ \\
\hline Bisikan & $\begin{array}{l}\text { Kata 'bisikan' mempunyai } \\
\text { arti kata yaitu 'bisa'. Istilah } \\
\text { ini biasanya digunakan oleh } \\
\text { kelompok sosial transeksual } \\
\text { ketika customer meminta } \\
\text { model rambut yang } \\
\text { diinginkanya. }\end{array}$ \\
\hline
\end{tabular}

\begin{tabular}{|c|c|}
\hline Blejongan & $\begin{array}{l}\text { Kata 'blejongan' mempunyai } \\
\text { arti kata yaitu 'belanja'. } \\
\text { Istilah ini biasanya digunakan } \\
\text { oleh kelompok sosial } \\
\text { transeksual ketika akan pergi } \\
\text { belanja barang kebutuhan } \\
\text { salon. }\end{array}$ \\
\hline Bodrexin & $\begin{array}{l}\text { Kata 'bodrexin' mempunyai } \\
\text { arti kata yaitu 'bodoh'. Istilah } \\
\text { ini biasanya digunakan oleh } \\
\text { kelompok sosial transeksual } \\
\text { ketika memaki sesama } \\
\text { transeksual ketika } \\
\text { pekerjaannya dianggap tidak } \\
\text { baik dan mendapat keluhan } \\
\text { dari customer. }\end{array}$ \\
\hline Bolenawati & $\begin{array}{l}\text { Kata 'bolenawati' } \\
\text { mempunyai arti kata yaitu } \\
\text { 'boleh'. Istilah ini biasanya } \\
\text { digunakan oleh kelompok } \\
\text { sosial transeksual ketika } \\
\text { memberikan izin kepada } \\
\text { temannya (transeksual) untuk } \\
\text { pergi mencari makan atau } \\
\text { sekedar ingin melepas penat } \\
\text { dari salon. }\end{array}$ \\
\hline Brepongan & $\begin{array}{l}\text { Kata 'brepongan' } \\
\text { mempunyai arti kata yaitu } \\
\text { 'berapa'. Istilah ini biasanya } \\
\text { digunakan oleh kelompok } \\
\text { sosial transeksual ketika } \\
\text { bertanya tentang harga } \\
\text { barang kebutuhan salon yang } \\
\text { ditawarkan oleh salesmen. }\end{array}$ \\
\hline Cakra & $\begin{array}{l}\text { Kata 'cakra' mempunyai arti } \\
\text { kata yaitu 'cakep atau } \\
\text { ganteng'. Istilah ini biasanya } \\
\text { digunakan oleh kelompok } \\
\text { sosial transeksual untuk } \\
\text { memuji customer laki-laki } \\
\text { tampan yang datang ke salon. }\end{array}$ \\
\hline Capcus & $\begin{array}{l}\text { Kata 'capcus' mempunyai } \\
\text { arti kata yaitu 'cepat'. Istilah } \\
\text { ini biasanya digunakan oleh } \\
\text { kelompok sosial transeksual } \\
\text { untuk memberi perintah } \\
\text { kepada asistenya } \\
\text { (transeksual) untuk segera } \\
\text { menyelesaikan pekerjaanya } \\
\text { yang dianggap lambat dalam } \\
\text { melayani kepada customer. }\end{array}$ \\
\hline Capung & $\begin{array}{l}\text { Kata 'capung' mempunyai } \\
\text { arti kata yaitu 'capek'. Istilah } \\
\text { ini biasanya digunakan oleh } \\
\text { kelompok sosial transeksual } \\
\text { untuk memberi informasi }\end{array}$ \\
\hline
\end{tabular}


Lanjutan Tabel 2 Tabel Keterangan Kosakata Seharihari

\begin{tabular}{|c|c|}
\hline & $\begin{array}{l}\text { kepada sesama traneksual } \\
\text { jika dirinya (transeksual) } \\
\text { merasa capek melayani } \\
\text { customer yang datang. }\end{array}$ \\
\hline Celenong & $\begin{array}{l}\text { Kata 'celenong' mempunyai } \\
\text { arti kata yaitu 'celana'. } \\
\text { Istilah ini biasanya digunakan } \\
\text { oleh kelompok sosial } \\
\text { transeksual untuk memberi } \\
\text { informasi kepada customer } \\
\text { yang hendak memesan celana } \\
\text { untuk acara resepsi } \\
\text { pernikahan. }\end{array}$ \\
\hline Desek & $\begin{array}{l}\text { Kata 'desek' mempunyai arti } \\
\text { kata yaitu 'dia'. Istilah ini } \\
\text { biasanya digunakan oleh } \\
\text { kelompok sosial transeksual } \\
\text { untuk memberi informasi } \\
\text { kepada sesama transeksual } \\
\text { nama seseorang yang sedang } \\
\text { dibicarakan. }\end{array}$ \\
\hline Duding & $\begin{array}{l}\text { Kata 'duding' mempunyi arti } \\
\text { kata yaitu 'duduk'. Istilah ini } \\
\text { biasanya digunakan oleh } \\
\text { kelompok sosial transeksual } \\
\text { untuk memberi perintah } \\
\text { kepada customer yang datang } \\
\text { untuk duduk. }\end{array}$ \\
\hline Duta & $\begin{array}{l}\text { Kata 'duta' mempunyai arti } \\
\text { kata yaitu 'uang'. Istilah ini } \\
\text { biasanya digunakan oleh } \\
\text { kelompok sosial transeksual } \\
\text { untuk memberi informasi } \\
\text { kepada sesama transeksual } \\
\text { tentang uang yang harus } \\
\text { dibayar customer jika } \\
\text { melakukan perawatan di } \\
\text { salon. }\end{array}$ \\
\hline Ekek & $\begin{array}{l}\text { Kata 'ekek' mempunyai arti } \\
\text { kata yaitu 'saya'. Istilah ini } \\
\text { biasanya digunakan oleh } \\
\text { kelompok sosial transeksual } \\
\text { untuk memberi informasi } \\
\text { identitas dirinya. }\end{array}$ \\
\hline Enem pelong & $\begin{array}{l}\text { Kata 'enem pelong' } \\
\text { mempunyai arti kata yaitu } \\
\text { 'enam puluh ribu rupiah'. } \\
\text { Istilah ini biasanya digunakan } \\
\text { oleh kelompok sosial } \\
\text { transeksual untuk memberi } \\
\text { informasi kepada sesama } \\
\text { transeksual jika hendak } \\
\text { menawarkan produk } \\
\text { kecantikan kepada customer. }\end{array}$ \\
\hline
\end{tabular}

\begin{tabular}{|c|c|}
\hline Enem pelong & $\begin{array}{l}\text { Kata 'enem pelong' } \\
\text { mempunyai arti kata yaitu } \\
\text { 'enam puluh ribu rupiah'. } \\
\text { Istilah ini biasanya digunakan } \\
\text { oleh kelompok sosial } \\
\text { transeksual untuk memberi } \\
\text { informasi kepada sesama } \\
\text { transeksual jika hendak } \\
\text { menawarkan produk } \\
\text { kecantikan kepada customer. }\end{array}$ \\
\hline Etes-etes & $\begin{array}{l}\text { Kata 'etes-etes' mempunyai } \\
\text { arti kata yaitu 'hati-hati'. } \\
\text { Istilah ini biasanya digunakan } \\
\text { oleh kelompok sosial } \\
\text { transeksual saat memberikan } \\
\text { perintah kepada customer } \\
\text { untuk hati-hati dalam } \\
\text { perjalanan pulang dari salon. }\end{array}$ \\
\hline Eyes & $\begin{array}{l}\text { Kata 'eyes' mempunyai arti } \\
\text { kata yaitu 'cantik'. Istilah ini } \\
\text { biasanya digunakan oleh } \\
\text { kelompok sosial transeksual } \\
\text { untuk memuji dirinya sendiri } \\
\text { ketika sedang berkumpul } \\
\text { dengan sesama transeksual di } \\
\text { salon. }\end{array}$ \\
\hline Gegong & $\begin{array}{l}\text { Kata 'gegong' mempunyai } \\
\text { arti kata yaitu 'gigi'. Istilah } \\
\text { ini biasanya digunakan oleh } \\
\text { kelompok sosial transesksual } \\
\text { untuk mengejek customer } \\
\text { yang bergigi tonggos. }\end{array}$ \\
\hline Gejongan & $\begin{array}{l}\text { Kata 'gejongan' mempunyai } \\
\text { arti kata yaitu 'gajian'. Istilah } \\
\text { ini biasanya digunakan oleh } \\
\text { kelompok sosial transeksual } \\
\text { untuk memberi informasi } \\
\text { kepada asistenya tanggal } \\
\text { gajian. }\end{array}$ \\
\hline Gembala & $\begin{array}{l}\text { Kata 'gembala' mempunyai } \\
\text { arti kata yaitu 'gemuk'. Istilah } \\
\text { ini biasanya digunakan oleh } \\
\text { kelompok sosial transeksual } \\
\text { untuk mengejek sesama } \\
\text { transeksual lainya yang } \\
\text { mempunyai berat badan } \\
\text { berlebih atau gemuk. }\end{array}$ \\
\hline Grimsi & $\begin{array}{l}\text { Kata 'grimsi' mempunyai arti } \\
\text { kata yaitu 'gerimis'. Istilah } \\
\text { ini biasanya digunakan oleh } \\
\text { kelompok sosial transeksual } \\
\text { untuk memberikan informasi } \\
\text { kepada sesama transeksual } \\
\text { jika ditempatnya ia bekerja } \\
\text { sedang gerimis. }\end{array}$ \\
\hline
\end{tabular}


Lanjutan Tabel 2 Tabel Keterangan Kosakata Seharihari

\begin{tabular}{|c|c|}
\hline Habibah & $\begin{array}{l}\text { Kata 'habibah' mempunyai } \\
\text { arti kata yaitu 'habis'. Istilah } \\
\text { ini biasanya digunakan oleh } \\
\text { kelompok sosial transeksual } \\
\text { untuk memberikan informasi } \\
\text { kepada sesama transeksual } \\
\text { saat barang kebutuhan salon } \\
\text { sudah habis. }\end{array}$ \\
\hline Harem & $\begin{array}{l}\text { Kata 'harem' mempunyai arti } \\
\text { kata yaitu 'jelek'. Istilah ini } \\
\text { biasanya digunakan oleh } \\
\text { kelompok sosial transeksual } \\
\text { untuk mengejek seseorang } \\
\text { yang dianggapnya jelek. }\end{array}$ \\
\hline Helmi yahya & $\begin{array}{l}\text { Kata 'helmi yahya' } \\
\text { mempunyai arti kata 'helm'. } \\
\text { Istilah ini biasanya digunakan } \\
\text { oleh kelompok sosial } \\
\text { transeksual untuk memberi } \\
\text { informasi nama kata benda } \\
\text { 'helm'. }\end{array}$ \\
\hline Hempina & $\begin{array}{l}\text { Kata 'hempina' mempunyai } \\
\text { arti kata yaitu 'handphone'. } \\
\text { Istilah ini biasanya digunakan } \\
\text { oleh kelompok sosial } \\
\text { transeksual untuk memberi } \\
\text { informasi nama kata benda } \\
\text { 'handphone'. }\end{array}$ \\
\hline Hitachi & $\begin{array}{l}\text { Kata 'hitachi' mempunyai } \\
\text { arti kata yaitu 'hitam'. Istilah } \\
\text { ini biasanya digunakan oleh } \\
\text { kelompok sosial transeksual } \\
\text { untuk memaki orang yang } \\
\text { mempunyai atau berkulit } \\
\text { hitam. }\end{array}$ \\
\hline Husni & $\begin{array}{l}\text { Kata 'husni’ mempunyi arti } \\
\text { kata yaitu 'hujan'. Istilah ini } \\
\text { biasanya digunakan oleh } \\
\text { kelompok sosial transeksual } \\
\text { untuk memberi informasi } \\
\text { kepada sesama transeksual } \\
\text { jika di tempat ia berkerja atau } \\
\text { salon sedang turun hujan. }\end{array}$ \\
\hline Ikatan & $\begin{array}{l}\text { Kata 'ikatan' mempunyai arti } \\
\text { kata yaitu 'ikut'. Istilah ini } \\
\text { biasanya digunakan oleh } \\
\text { kelompok sosial transeksual } \\
\text { untuk mengajak sesama } \\
\text { transeksual untuk pergi } \\
\text { berbelanja barang kebutuhan } \\
\text { salon. }\end{array}$ \\
\hline
\end{tabular}

\begin{tabular}{|c|c|}
\hline Ines & $\begin{array}{l}\text { Kata 'ines' mempunyai arti } \\
\text { kata yaitu 'ini'. Istilah ini } \\
\text { biasanya digunakan oleh } \\
\text { kelompok sosial transeksual } \\
\text { untuk memberi informasi } \\
\text { kepada temannya sesama } \\
\text { transeksual letak barang yang } \\
\text { dicari atau diinginkan. }\end{array}$ \\
\hline Isabella & $\begin{array}{l}\text { Kata 'isabella' mempunyai } \\
\text { arti kata yaitu 'di sebelah'. } \\
\text { Istilah ini biasanya digunakan } \\
\text { oleh kelompok sosial } \\
\text { transeksual untuk memberi } \\
\text { informasi seseorang yang } \\
\text { berada di sebelahnya. }\end{array}$ \\
\hline Isnaini & $\begin{array}{l}\text { Kata 'isnaini' mempunyi arti } \\
\text { kata yaitu 'malu'. Istilah ini } \\
\text { biasanya digunakan oleh } \\
\text { kelompok sosial transeksual } \\
\text { jika dirinya merasa malu jika } \\
\text { ditanya sesuatu oleh } \\
\text { customer. }\end{array}$ \\
\hline Jakarta & $\begin{array}{l}\text { Kata 'Jakarta' mempunyai } \\
\text { arti kata yaitu 'jaket'. Istilah } \\
\text { ini biasanya digunakan oleh } \\
\text { kelompok sosial transeksual } \\
\text { untuk memberi perintah } \\
\text { kepada sesama transeksual } \\
\text { untuk mengambil jaket yang } \\
\text { diinginkan. }\end{array}$ \\
\hline Jali-jali & $\begin{array}{l}\text { Kata 'jali-jali’ mempunyai } \\
\text { arti kata yaitu 'jalan-jalan'. } \\
\text { Istilah ini biasanya digunakan } \\
\text { oleh kelompok sosial } \\
\text { transeksual untuk mengajak } \\
\text { sesama transeksual untuk } \\
\text { pergi 'jalan-jalan'. }\end{array}$ \\
\hline Jauhari & $\begin{array}{l}\text { Kata 'jauhari' mempunyai } \\
\text { arti kata yaitu 'jauh'. Istilah } \\
\text { ini biasanya digunakan oleh } \\
\text { kelompok sosial transeksual } \\
\text { saat merasa jengkel jika letak } \\
\text { rumah customer yang akan } \\
\text { punya hajat terlalu jauh untuk } \\
\text { didatangi. }\end{array}$ \\
\hline Jelita & $\begin{array}{l}\text { Kata 'jelita' mempunyai arti } \\
\text { kata 'jelek'. Istilah ini } \\
\text { biasanya digunakan oleh } \\
\text { kelompok sosial transeksual } \\
\text { untuk memaki sesama } \\
\text { transeksual yang dianggap } \\
\text { jelek atau biasa-biasa saja } \\
\text { dalam hal berpenampilan. }\end{array}$ \\
\hline
\end{tabular}


Lanjutan Tabel 2 Tabel Keterangan Kosakata Seharihari

\begin{tabular}{|c|c|}
\hline Jembong & $\begin{array}{l}\text { Kata 'jembong' mempunyai } \\
\text { arti kata yaitu 'menjambak'. } \\
\text { Istilah ini biasanya digunakan } \\
\text { oleh kelompok sosial } \\
\text { transeksual saat dirinya } \\
\text { merasa jengkel kepada } \\
\text { temanya (transeksual) dan } \\
\text { hendak menjambak } \\
\text { rambutnya. }\end{array}$ \\
\hline Jula-juli & $\begin{array}{l}\text { Kata 'jula-juli’ mempunyai } \\
\text { arti kata yaitu 'jual-beli'. } \\
\text { Istilah ini biasanya digunakan } \\
\text { oleh kelompok sosial } \\
\text { transeksual untuk } \\
\text { memberikan informasi } \\
\text { kepada salesman barang } \\
\text { kebutuhan salon yang } \\
\text { menawarkan produk } \\
\text { kecantikan salon. }\end{array}$ \\
\hline Kampingan & $\begin{array}{l}\text { Kata ‘kampingan' } \\
\text { mempunyai arti kata yaitu } \\
\text { 'kapan'. Istilah ini biasanya } \\
\text { digunakan oleh kelompok } \\
\text { sosial transeksual untuk } \\
\text { bertanya kepada sesama } \\
\text { transeksual kapan jadwal } \\
\text { bermain voli dilaksanakan. }\end{array}$ \\
\hline Katarina & $\begin{array}{l}\text { Kata 'katarina' mempunyai } \\
\text { arti kata yaitu 'kotor'. Istilah } \\
\text { ini biasanya digunakan oleh } \\
\text { kelompok sosial transeksual } \\
\text { untuk memberi perintah } \\
\text { kepada asisiten (transeksual) } \\
\text { ketika salon sudah dalam } \\
\text { keadaan tidak bersih atau } \\
\text { kotor. }\end{array}$ \\
\hline Kayangan & $\begin{array}{l}\text { Kata 'kayangan' mempunyai } \\
\text { arti kata yaitu 'kaya'. Istilah } \\
\text { ini biasanya digunakan oleh } \\
\text { kelompok sosial transeksual } \\
\text { untuk memberi informasi } \\
\text { kepada sesama transeksual } \\
\text { tentang customer yang datang } \\
\text { dan dianggapnnya 'kaya'. }\end{array}$ \\
\hline Kekong & $\begin{array}{l}\text { Kata 'kekong' mempunyai } \\
\text { arti kata yaitu 'kaki'. Istilah } \\
\text { ini biasanya digunakan oleh } \\
\text { kelompok sosial transeksual } \\
\text { untuk memberikan nasihat } \\
\text { kepada customer untuk } \\
\text { melakukan perawatan kaki. }\end{array}$ \\
\hline
\end{tabular}

\begin{tabular}{|c|c|}
\hline Keles & $\begin{array}{l}\text { Kata 'keles' mempunyai arti } \\
\text { kata yaitu 'sungai'. Istilah ini } \\
\text { biasanya digunakan oleh } \\
\text { kelompok sosial transeksual } \\
\text { untuk memberikan informasi } \\
\text { kepada sesama transeksual } \\
\text { yang bertanya tentang tempat } \\
\text { bernama kali atau sungai. }\end{array}$ \\
\hline Kemandra & $\begin{array}{l}\text { Kata 'kemandra' mempunyai } \\
\text { arti kata yaitu 'kemana'. } \\
\text { Istilah ini biasanya digunakan } \\
\text { oleh kelompok sosial } \\
\text { transeksual untuk bertanya } \\
\text { kepada sesama transeksual } \\
\text { yang hendak pergi. }\end{array}$ \\
\hline Kentucky & $\begin{array}{l}\text { Kata 'kentucky' mempunyai } \\
\text { arti kata yaitu 'kentut'. Istilah } \\
\text { ini biasanya digunakan oleh } \\
\text { kelompok sosial transeksual } \\
\text { ketika merasa jengkel ada } \\
\text { bau yang tidak sedap di } \\
\text { salon. }\end{array}$ \\
\hline Kerintangan & $\begin{array}{l}\text { Kata 'kerintangan' } \\
\text { mempunyai arti kata yaitu } \\
\text { 'keriting'. Istilah ini biasanya } \\
\text { digunakan oleh kelompok } \\
\text { sosial transeksual untuk } \\
\text { bertanya kepada customer } \\
\text { ingin dimodel seperti apa } \\
\text { rambutnya. }\end{array}$ \\
\hline Kerajaan & $\begin{array}{l}\text { Kata 'kerajaan' mempunyai } \\
\text { arti kata yaitu 'kerja'. Istilah } \\
\text { ini biasanya digunakan oleh } \\
\text { kelompok sosial transeksual } \\
\text { untuk memberikan informasi } \\
\text { kepada sesama transeksual } \\
\text { saat dirinya (transeksual) } \\
\text { sedang berker melayani } \\
\text { customer. }\end{array}$ \\
\hline Keredongan & $\begin{array}{l}\text { Kata 'keredongan' } \\
\text { mempunyai arti kata yaitu } \\
\text { 'kerudungan'. Istilah ini } \\
\text { biasanya digunakan oleh } \\
\text { kelompok sosial transeksual } \\
\text { untuk memberi informasi } \\
\text { kepada customer bahwa ada } \\
\text { pengantin yang menggunakan } \\
\text { kerudung dalam acara resepsi } \\
\text { pernikahan. }\end{array}$ \\
\hline Kulsek & $\begin{array}{l}\text { Kata 'kulsek' mempunyai arti } \\
\text { kata yaitu 'kuliah'. Istilah ini } \\
\text { biasanya digunakan oleh } \\
\text { kelompok sosial transeksual } \\
\text { saat bertanya kepada } \\
\text { customer tentang identitasnya } \\
\text { yang berstatus sebagai } \\
\text { mahasiswa. }\end{array}$ \\
\hline
\end{tabular}


Lanjutan Tabel 2 Tabel Keterangan Kosakata Seharihari

\begin{tabular}{|c|c|}
\hline Kuncira & $\begin{array}{l}\text { Kata 'kuncira' mempunyai } \\
\text { arti kata yaitu 'kunci'. Istilah } \\
\text { ini biasanya digunakan oleh } \\
\text { kelompok sosial transeksual } \\
\text { untuk memberi informasi } \\
\text { letak kunci yang dimaksud } \\
\text { sesama transeksual lainya. }\end{array}$ \\
\hline Kurnia & $\begin{array}{l}\text { Kata 'kurnia' mempunyai arti } \\
\text { kata yaitu 'kurang'. Istilah ini } \\
\text { biasanya digunakan oleh } \\
\text { kelompok sosial transeksual } \\
\text { untuk memberi informasi } \\
\text { kepada sesama transeksual } \\
\text { jika ada hal yang dirasa } \\
\text { kurang, seperti uang } \\
\text { pembayaran dari customer } \\
\text { dan lain sebagainya. }\end{array}$ \\
\hline Lacita & $\begin{array}{l}\text { Kata 'lacita' mempunyai arti } \\
\text { kata yaitu 'lancang'. Istilah } \\
\text { ini biasanya digunakan oleh } \\
\text { kelompok sosial transeksual } \\
\text { jika dirinya (transeksual) } \\
\text { merasa jengkel kepada } \\
\text { sesama transeksual karena } \\
\text { suatu hal. }\end{array}$ \\
\hline Lambreta & $\begin{array}{l}\text { Kata 'lambreta' mempunyai } \\
\text { arti kata yaitu 'lambat'. } \\
\text { Istilah ini biasanya digunakan } \\
\text { oleh kelompok sosial } \\
\text { transeksual untuk memaki } \\
\text { sesama transeksual yang } \\
\text { dirasa lambat dalam melayani } \\
\text { customer. }\end{array}$ \\
\hline Lamongan & $\begin{array}{l}\text { Kata 'lamongan' mempunyai } \\
\text { arti kata yaitu 'lama'. Istilah } \\
\text { ini biasanya digunakan oleh } \\
\text { kelompok sosial transeksual } \\
\text { untuk menunjukkan rasa } \\
\text { jengkelnya ketika harus } \\
\text { menunggu temannya yang } \\
\text { lama datang ke salon. }\end{array}$ \\
\hline Lampringan & $\begin{array}{l}\text { Kata 'lampringan’ } \\
\text { mempunyai arti kata yaitu } \\
\text { 'sedang apa'. Istilah ini } \\
\text { biasanya digunakan oleh } \\
\text { kelompok sosial transeksual } \\
\text { ketika bertanya kepada } \\
\text { temanya (transeksual) saat } \\
\text { bebicara lewat telfon }\end{array}$ \\
\hline Lapangan bola & $\begin{array}{l}\text { Kata 'lapangan bola' } \\
\text { mempunyai arti kata yaitu ' } \\
\text { lapar'. Istilah ini biasanya } \\
\text { digunakan oleh kelompok } \\
\text { sosial transeksual untuk }\end{array}$ \\
\hline
\end{tabular}

\begin{tabular}{|c|c|}
\hline & $\begin{array}{l}\text { memberikan informasi } \\
\text { kepada sesama transeksual } \\
\text { jika dirinya (transeksual) } \\
\text { merasa lapar. }\end{array}$ \\
\hline Lebrong & $\begin{array}{l}\text { Kata 'lebrong' mempunyai } \\
\text { arti kata yaitu 'libur'. Istilah } \\
\text { ini biasanya digunakan oleh } \\
\text { kelompok sosial transeksual } \\
\text { untuk memberi informasi } \\
\text { kepada temanya (transeksual) } \\
\text { jika acara arisan sedang libur. }\end{array}$ \\
\hline Lehes & $\begin{array}{l}\text { Kata 'lehes' mempunyai arti } \\
\text { kata yaitu 'lihat'. Istilah ini } \\
\text { biasanya digunakan oleh } \\
\text { kelompok sosial transeksual } \\
\text { untuk memberikan informasi } \\
\text { kepada sesama transeksual } \\
\text { untuk segera melihat sesuatu } \\
\text { yang telah ditunjuk, seperti } \\
\text { laki-laki ganteng yang lewat } \\
\text { di depan salon. }\end{array}$ \\
\hline Limang pelong & $\begin{array}{l}\text { Kata 'limang pelong' } \\
\text { mempunyai arti kata yaitu } \\
\text { 'lima puluh ribu rupiah'. } \\
\text { Istilah ini biasanya digunakan } \\
\text { oleh kelompok sosial } \\
\text { transeksual untuk } \\
\text { memberikan informasi } \\
\text { kepada customer tentang } \\
\text { harga produk kecantikan } \\
\text { yang diinginkan. }\end{array}$ \\
\hline Lupita & $\begin{array}{l}\text { Kata 'lupita' mempunyai arti } \\
\text { kata yaitu 'lupa'. Istilah ini } \\
\text { biasanya digunakan oleh } \\
\text { kelompok sosial transeksual } \\
\text { untuk memberikan informasi } \\
\text { kepada customer tentang } \\
\text { harga produk kecantikan } \\
\text { yang diinginkan customer. }\end{array}$ \\
\hline Makasar & $\begin{array}{l}\text { Kata 'makasar' mempunyai } \\
\text { arti kata yaitu 'makan'. } \\
\text { Istilah ini biasanya digunakan } \\
\text { oleh kelompok sosial } \\
\text { transeksual untuk memberi } \\
\text { perintah kepada temannya } \\
\text { (transeksual) untuk segera } \\
\text { makan jika jam makan siang } \\
\text { sudah datang. }\end{array}$ \\
\hline Mak lampir & $\begin{array}{l}\text { Kata 'mak lampir' } \\
\text { mempunyai arti kata yaitu } \\
\text { 'malam'. Istilah ini biasanya } \\
\text { digunakan oleh kelompok } \\
\text { sosial transeksual untuk } \\
\text { memberi informasi kepada } \\
\text { sesama transeksual untuk } \\
\text { segera menutup salon karena } \\
\text { dirasa sudah malam. }\end{array}$ \\
\hline
\end{tabular}


Lanjutan Tabel 2 Tabel Keterangan Kosakata Seharihari

\begin{tabular}{|c|c|}
\hline Malaysia & $\begin{array}{l}\text { Kata 'malaysia' mempunyai } \\
\text { arti kata yaitu 'malas'. Istilah } \\
\text { ini biasanya digunakan oleh } \\
\text { kelompok sosial transeksual } \\
\text { untuk memaki kelompok } \\
\text { sosial transeksual lainya yang } \\
\text { malas-malasan dalam } \\
\text { berkerja melayani customer. }\end{array}$ \\
\hline Manda & $\begin{array}{l}\text { Kata 'manda' mempunyai } \\
\text { arti kata yaitu 'mana'. Istilah } \\
\text { ini biasanya digunakan oleh } \\
\text { kelompok sosial transeksual } \\
\text { untuk bertanya tentang } \\
\text { sesuatu hal kepada sesama } \\
\text { transeksual. }\end{array}$ \\
\hline Mandala & $\begin{array}{l}\text { Kata 'mandala' mempunyai } \\
\text { arti kata yaitu 'mandi'. Istilah } \\
\text { ini biasanya digunakan oleh } \\
\text { kelompok sosial transeksual } \\
\text { untuk memberi nasehat } \\
\text { kepada sesama transeksual } \\
\text { untuk segera mandi setelah } \\
\text { jam kerja selesai. }\end{array}$ \\
\hline Maskap & $\begin{array}{l}\text { Kata 'maskap' mempunyai } \\
\text { arti kata yaitu 'masuk'. Istilah } \\
\text { ini biasanya digunakan oleh } \\
\text { kelompok sosial traseksual } \\
\text { untuk mengajak dan } \\
\text { mempersilahkan customer } \\
\text { yang datang untuk segera } \\
\text { masuk ke dalam salon. }\end{array}$ \\
\hline Mehong & $\begin{array}{l}\text { Kata 'mehong' mempunyai } \\
\text { arti kata yaitu 'mahal'. Istilah } \\
\text { ini biasanya digunakan oleh } \\
\text { kelompok sosial transeksual } \\
\text { saat dirinya (transeksual) } \\
\text { merasa jengkel ketika barang } \\
\text { kebutuhan salon yang hendak } \\
\text { dibeli dinilai sangat mahal. }\end{array}$ \\
\hline Merana & $\begin{array}{l}\text { Kata 'merana' mempunyai } \\
\text { arti kata yaitu 'merah'. Istilah } \\
\text { ini biasanya digunakan oleh } \\
\text { kelompok sosial transeksual } \\
\text { untuk bertanya kepada } \\
\text { customer tentang baju dengan } \\
\text { warna apa yang diinginkan } \\
\text { untuk acara resepsi } \\
\text { pernikahan yang sudah } \\
\text { dipesan. }\end{array}$ \\
\hline Merong & $\begin{array}{l}\text { Kata 'merong' mempunyai } \\
\text { arti kata yaitu 'marah'. Istilah } \\
\text { ini biasanya digunakan oleh } \\
\text { kelompok sosial transeksual } \\
\text { untuk memberi informasi }\end{array}$ \\
\hline
\end{tabular}

\begin{tabular}{|c|c|}
\hline & $\begin{array}{l}\text { kepada sesama transeksual } \\
\text { ketika customer marah dan } \\
\text { merasa hasil pelayanan } \\
\text { kurang maksimal. }\end{array}$ \\
\hline Metes & $\begin{array}{l}\text { Kata 'metes' mempunyai arti } \\
\text { kata yaitu 'mati'. Istilah ini } \\
\text { biasanya digunakan oleh } \\
\text { kelompok sosial transeksual } \\
\text { ketika merasa jengkel ketika } \\
\text { sedang bekerja melayani } \\
\text { custumer tiba-tiba listrik di } \\
\text { dalam salon mati. }\end{array}$ \\
\hline Minentiner & $\begin{array}{l}\text { Kata 'minentiner' } \\
\text { mempunyai arti kata yaitu } \\
\text { 'terlalu percaya diri'. Istilah } \\
\text { ini biasanya digunakan oleh } \\
\text { kelompok sosial transeksual } \\
\text { ketika mengejek seseorang } \\
\text { yang diangapnya terlalu } \\
\text { percaya diri. Biasanya } \\
\text { ditujukan kepada perempuan. }\end{array}$ \\
\hline Minima & $\begin{array}{l}\text { Kata 'minima' mempunyai } \\
\text { arti kata yaitu 'minum'. } \\
\text { Istilah ini biasanya digunakan } \\
\text { oleh kelompok sosial } \\
\text { transeksual untuk memohon } \\
\text { diambilkan sesuatu yang } \\
\text { diinginkan kepada sesama } \\
\text { transeksual. }\end{array}$ \\
\hline Miskana & $\begin{array}{l}\text { Kata 'miskana' mempunyai } \\
\text { arti kata yaitu 'miskin'. Istilah } \\
\text { ini biasanya digunakan oleh } \\
\text { kelompok sosial transeksual } \\
\text { untuk memberikan informasi } \\
\text { kepada sesama transeksual } \\
\text { jika sedang tidak mempunyai } \\
\text { uang. }\end{array}$ \\
\hline Mukria & $\begin{array}{l}\text { Kata 'mukria' mempunyai } \\
\text { arti kata yaitu 'muka'. Istilah } \\
\text { ini biasanya digunakan oleh } \\
\text { kelompok sosial transeksual } \\
\text { untuk memuji seseorang yang } \\
\text { bermuka putih dan bersih } \\
\text { yang datang ke salon. }\end{array}$ \\
\hline Ngantra & $\begin{array}{l}\text { Kata 'ngantra' mempunyai } \\
\text { arti kata yaitu 'mengantuk'. } \\
\text { Istilah ini biasanya digunakan } \\
\text { oleh kelompok sosial } \\
\text { transeksual untuk memberi } \\
\text { informasi kepada sesama } \\
\text { transeksual jika dirinya } \\
\text { merasa mengantuk. }\end{array}$ \\
\hline Ngobras-ngobras & $\begin{array}{l}\text { Kata 'ngobras-ngobras' } \\
\text { mempunyai arti kata yaitu } \\
\text { 'ngomong-ngomong'. Istilah } \\
\text { ini biasanya digunakan oleh } \\
\text { kelompok sosial transeksual }\end{array}$ \\
\hline
\end{tabular}


Lanjutan Tabel 2 Tabel Keterangan Kosakata Seharihari

\begin{tabular}{|c|c|}
\hline & $\begin{array}{l}\text { kepada sesama transeksual } \\
\text { saat sedang melakukan } \\
\text { aktivitas berkumpul dan } \\
\text { membicarakan orang lain } \\
\text { dengan sesama transeksual di } \\
\text { salon. }\end{array}$ \\
\hline Ngumsek & $\begin{array}{l}\text { Kata 'ngumsek' mempunyai } \\
\text { arti kata yaitu 'mencuci'. } \\
\text { Istilah ini biasanya digunakan } \\
\text { oleh kelompok sosial } \\
\text { transeksual untuk mengajak } \\
\text { customer segera keramas } \\
\text { karena proses pelayanan } \\
\text { sudah selesai. }\end{array}$ \\
\hline Organda & $\begin{array}{l}\text { Kata 'organda' mempunyai } \\
\text { arti kata yaitu 'orang'. Istilah } \\
\text { ini biasanya digunakan oleh } \\
\text { kelompok sosial transeksual } \\
\text { untuk memberi informasi } \\
\text { kepada sesama transeksual } \\
\text { tentang orang yang sedang } \\
\text { dimaksud dalam sebuah } \\
\text { pembicaraan. }\end{array}$ \\
\hline Pagina & $\begin{array}{l}\text { Kata 'pagina' mempunyai } \\
\text { arti kata yaitu 'pagi'. Istilah } \\
\text { ini biasanya digunakan oleh } \\
\text { kelompok sosial transeksual } \\
\text { untuk memberi informasi } \\
\text { kepada sesama transeksual } \\
\text { jika waktu sudah menun- } \\
\text { jukkan waktu pagi hari. }\end{array}$ \\
\hline Pastelan & $\begin{array}{l}\text { Kata 'pastelan' mempunyai } \\
\text { arti kata yaitu 'pasti'. Istilah } \\
\text { ini biasanya digunakan oleh } \\
\text { kelompok sosial transeksual } \\
\text { untuk memberikan informasi } \\
\text { kepada sesama transeksual } \\
\text { akan kepastian datang } \\
\text { tidaknya kesuatu acara yang } \\
\text { sudah direncanakan. }\end{array}$ \\
\hline Pendekar & $\begin{array}{l}\text { Kata 'pendekar' mempunyai } \\
\text { arti kata yaitu 'pendek'. } \\
\text { Istilah ini biasanya digunakan } \\
\text { oleh kelompok sosial } \\
\text { transeksual untuk memaki } \\
\text { laki-laki yang mempunyai } \\
\text { postur tubuh 'pendekar' } \\
\text { (pendek tapi kekar). }\end{array}$ \\
\hline Peres & $\begin{array}{l}\text { Kata 'peres' mempunyai arti } \\
\text { kata yaitu 'bohong'. Istilah } \\
\text { ini biasanya digunakan oleh } \\
\text { kelompok sosial transeksual } \\
\text { saat dirinya (transeksual) } \\
\text { merasa jengkel kepada }\end{array}$ \\
\hline
\end{tabular}

\begin{tabular}{|c|c|}
\hline & $\begin{array}{l}\text { salesman barang kebutuhan } \\
\text { salon yang pandai berbicara } \\
\text { ketika menawarkan produk } \\
\text { kecantikan. }\end{array}$ \\
\hline Petang pelong & $\begin{array}{l}\text { Kata 'petang pelong' } \\
\text { mempunyai arti kata yaitu } \\
\text { 'empat puluh ribu rupiah'. } \\
\text { Istilah ini biasanya digunakan } \\
\text { oleh kelompok sosial } \\
\text { transeksual untuk } \\
\text { memberikan informasi harga } \\
\text { produk kecantikan yang } \\
\text { ditawarkan kepada customer. }\end{array}$ \\
\hline Pleni-pleni & $\begin{array}{l}\text { Kata 'pleni-pleni' } \\
\text { mempunyai arti kata yaitu } \\
\text { 'pelan-pelan'. Istilah ini } \\
\text { biasanya digunakan oleh } \\
\text { kelompok sosial transeksual } \\
\text { untuk memberi perintah } \\
\text { kepada asistennya } \\
\text { (transeksual) untuk pelan- } \\
\text { pelan dalam bekerja melayani } \\
\text { customer (mencatok rambut } \\
\text { customer). }\end{array}$ \\
\hline Polonia & $\begin{array}{l}\text { Kata 'polonia' mempunyai } \\
\text { arti kata yaitu 'pulang'. } \\
\text { Istilah ini biasanya digunakan } \\
\text { oleh kelompok sosial } \\
\text { transeksual untuk memberi } \\
\text { nasihat kepada sesama } \\
\text { transeksual untuk segera } \\
\text { pulang karena jam bekerja } \\
\text { sudah selesai. }\end{array}$ \\
\hline Prutinus & $\begin{array}{l}\text { Kata 'prutinus' mempunyai } \\
\text { arti kata yaitu 'perut'. Istilah } \\
\text { ini biasanya digunakan oleh } \\
\text { kelompok sosial transeksual } \\
\text { untuk mengajak sesama } \\
\text { transeksual untuk makan } \\
\text { karena perutnya sudah } \\
\text { merasa sangat lapar. }\end{array}$ \\
\hline Pulsinus & $\begin{array}{l}\text { Kata 'pulsinus' mempunyai } \\
\text { arti kata yaitu 'pulsa'. Istilah } \\
\text { ini biasanya digunakan oleh } \\
\text { kelompok sosial transeksual } \\
\text { saat memohon kepada sesama } \\
\text { transeksual untuk segera } \\
\text { membelikan pulsa } \\
\text { handphone. }\end{array}$ \\
\hline Putira & $\begin{array}{l}\text { Kata 'putira' mempunyai arti } \\
\text { kata yaitu 'putih'. Istilah ini } \\
\text { biasanya digunakan oleh } \\
\text { kelompok sosial transeksual } \\
\text { untuk memuji laki-laki yang } \\
\text { mempunyai kulit putih dan } \\
\text { bersih. }\end{array}$ \\
\hline
\end{tabular}


Berdasarkan Tabel 2 di atas, kosakata ini yang digunakan oleh kelompok transeksual sebagai tuturan kepada orang lain, di antaranya adalah kepada sesama transeksual, customer, dan salesman barang kebutuhan salon.

\section{KESIMPULAN}

Kosakata sehari-hari yang digunakan oleh kelompok sosial transeksual di Kecamatan Pakis Kabupaten Malang dapat diidentifikasi, bentuknya kurang lebih 100 wujud kosakata sehari-hari yang digunakan oleh kelompok sosial transeksual saat berkomunikasi. Selanjutnya kata-kata tersebut digunakan oleh kelompok transeksual di Kecamatan Pakis Kabupaten Malang sebagai tuturan kepada orang lain ataupun kepada sesama transeksual.

\section{DAFTAR PUSTAKA}

Chaer, Abdul \& Leoni Agustina. 1995. Sosiolinguistik Perkenalan Awal. Jakarta: Rineka Cipta.

Moleong, Lexy. 2005. Metodologi Penelitian Kualitatif. Bandung: remaja Rosdakarya.

Mujianto, Gigit. 2003. Sosiolinguistik dan Variasi Bahasa. Malang: UMM.

Nopianti, Kevin. 2007. Bahasa Slang Bahasa Indonesia Antarremaja Bekasi Jawa Barat (Telaah Terhadap Jenis Kata dan Fungsi Bahasa Slang). Skripsi tidak diterbitkan. Malang: Fakultas Keguruan dan Ilmu Pendidikan, Universitas Muhammadiyah Malang.

Pateda, Mansoer. 1987. Sosiolinguistik. Bandung: Angkasa.

Pateda, Mansoer. 1990. Sosiolinguistik. Bandung: Angkasa.

Sundari. 2007. Penggunaan Bahasa Prokem Waria Di Kota Trenggalek. Skripsi Tidak Diterbitkan. Malang: Fakultas Keguruan dan Ilmu Pendidikan, Universitas Muhammadiyah Malang.

Wurianto, Arif Budi. 2015. Kata Serapan Bahasa Sanskerta dalam Bahasa Indonesia. Jurnal KEMBARA, 1 (2): 125-134. 